\title{
Rational Political Behavior on Young Generation Voter
}

\author{
Mulyana Abdullah', Kama Abdul Hakam², Wilodati3, Ratna Fitria ${ }^{4}$ \\ Universitas Pendidikan Indonesia, Bandung, Indonesia
}

\begin{abstract}
The advance of political system in Indonesia show that there is the involvement of the political party that is in the interests of each party. It is causing diversity of consideration voters to determine the choice. For Indonesian people today, The rational aspects apparently started to influence the behavior of voters strongly to determine the choice either in general or regional election. The question that arise is hoe the educated young voter, as well as the students of UPI, to choose the leader of government, especially in election? Is the political rationality become the characteristics of their political behaviour? Through the research which is applied the quantitative research approach design and the object be focused in University of Indonesian Education (UPI), revealed that the main aspects which is becomes the consederation of the majority of respondents is vision and mission of political party/candidate. So does with the consideration of the candidate's experience and performance used as the basis of their decision to vote. Meanwhile, the assessment of political party will be a basis of respondents consideration in determining their choice. It is apparent from their assessment to the political parties that are during compete. So that, it can be conclude that people awareness, especially respondents as the voters show the political attitude critically in examining and assessing vision and mission of politicians. People have participated in politic actively with reviewed the political values of politician's promises as a form of their rationality of politic.
\end{abstract}

Keywords: election behaviour, novice voter, political-rational behaviour

Correspondence. abdullahmulyana@gmail.com

Article History. Received January 2019, Received in revised March 2019, Accepted June 2019

C2019. International Journal Pedagogy of Social Studies. Department of Social Studies Education

\section{A. INTRODUCTION}

Election in democratic countries, as well as Indonesia, is the arena of leader of state/government election which reflect the openness atmosphere by free of both argue and unite. Not only in choosing gouvernment leader, political participation of society in election become an arena of the community representatives in national legislature (DPR) or lokal legislature (DPRD).

Meanwhile, the advance of political system in Indonesia show that there is the involvement of the political party that is in the interests of each party. It is causing diversity of consideration voters to determine the choice. In generally, Indonesian people still holds a strong religious belief when choosing a leader, as given in the results of the study of Higashikata and Kawamura (2015, p. 23) who said that in general, the people who reside in the vicinity of the district with strong religious devotion in Islami will choose the Islamic parties. In their study, Higashikata and Kawamura (2015, p. 24) said:

... districts which formerly stood strongly behind Islamic parties continued to select those parties, or gave preference to abstention over the secular parties ... the effect of regional characteristics on the vote margin of Islamic parties, using aggregated panel data at the district level, and confirmed the positive correlations between them.

Altough, with the advance of science and technology where the communication of the international community is getting stronger and more intensive which causing interact each other in daily life, power of view and the perceptibility are included in, has led toward the rational scientific thinking. At the end, this shift had an impact on individual behavior in society, and it is so 
in behaviour to choose their representative in gouvernment.

For Indonesian people today, the rational aspect seems starting stronger in influencing voter behaviour to decide their choosen in election. It is unfold in Hasriani, Madani and Handam's study (2015, p. 63-64) in Gowa that shown the people choose a candidate with consider his/her achievement, success and leadership capacity and consider his/her performance before. Meanwhile, Azmi (2015, p. 7-8) concluded that the majority of people of Kendal-Midle Java Province choose the gouvernment leader based on his/her vision, mission and programe. They unaffected even from nearest, retain or candidate's glamour. Particularly in young voters, their rationality thinking is affected by education factor which are generally in higher education.

The both of studies show that there is a tend in their own (voters) to determine the choice rationally where the candidates who they choose be considered in their prowess and competences, and not to focuse on their religion background. It is strengthened by the results of the Zidny study (2014, p. 87), "The educated voters be quite rational in determining voting patterns and having an ideological even logical consideration".

If it is true, the quetions that appear are: how is the political behaviour of the educated young voters, as well as the students of Universitas Pendidikan Indonesia (UPI) to choose the gouvernment leader, esspecially in election? Will the political rational became their political behaviour, too?

Based on the rational that has been described, this study is trying to address the political rationality of young generation, esspecially the students of UPI in election, that is: how is the political behaviour rationality of students of UPI in election?

\section{B. METHOD}

Referring to the matter above, this research implemented quantitative approach research design which is the reality of the object is concrete, observed, able to be classified and measurable (Sugiyono, 2012: 10). This study has be choosen to reveal the tendency of political behaviour oaf the students of UPI as novice voters in election.

This study is conducted with focusing the object on Universitas Pendidikan Indonesia (UPI) based on consideration that the youth as eligible voters, especially as novice voters in the vicinity of the higher education is identified as a subject who can be described as someone who has high education relatively and capable for using the perceptibility and thinking objectively in taking a decision, which in this case is the rationality of election behaviour in the election process in Indonesia.

All the subjects in this study as the population are the youngest students of UPI in 2017/2018 academic periode as many as 2,428 persons who instead are widely scattered in 31 departments or programs and divided into 62 study groups. Meanwhile the large number of sample set using Dixon dan Leach (1977: 8) formula as many as 240 persons of the moslem students.

\section{LITERATURE REVIEW}

\section{The basic concept of voting behaviour}

Behavior in general can be seen as everything no matter what the or course of action that have been done by someone, behaviour is the essential characteristics of a person to perform the certain activities which is the mixed results from a variety of psychological, physical, and biological factors, and social conditions affect the human life.

Walgito (Marjohan, 2014: 16) suggested that behavior is the individua 
activity, in a wider sense includes the overt behavior and innert behaviour. Behavior in the soul of individual not arising by itself, but as a result of a stimulus that be accepted by individuals both external stimulus and internal stimulus.

In the study of voting behaviour, Antunes (2010: 146) suggested that at least there are three models in the study of election behavior, which are sociological models that be identified as Columbia model which is focused on the influence of social factors; phsychological model that be identified as Michigan model which views that party identification is the main factor behind election behavior and the voters; and rational choice theory or economic model that be identified as Rochester model which is based on economic theory of democracy.

\section{Rational choice theory in chosing}

"A politician or a political party has to see the level of rationality of their vision-mission". This matters is mentioned by Salahudin (2016, p. 2) in his article that related to rationality of political promise in local election in Indonesia. And then, Salahudin (2016, p. 2 ) said that the rationality level of visionmission which is promised by politicians or political parties is relating to: (1) are the vision-mission can be applicated? (2) are the vision-mission be balanced with organization resources? (3) are the vision-mission have the values of humanity? And (4) are the vision-mission referring to the national ideology? This vision-mission will become the indicators for people to make decisions to choose that politician/political party or not.

In 1990, Steiner (1990, p. 48) based on Gabriel A. Almond and David McKay point of view, affirm "Politicians would have a relatively short time perspective because the next election is always just around the corner. If the issue were". It is suggested that the voters trust to politician/political party is highly determined by the success of the politician or political party manifesting their vision-mission that they made before, so that, in the next election will be consideration of voter to choose again or not. It seem that voters decision based on the view which is called "rational choice".

Election behaviour is not permanent, as well as sociological characteristics and party ID, but it can change appropriate to the time and events on fundamental problems. In this case, the political issues would be the main consideration. The voters can decide their choice based on assessment of the political issues and prediction of candidates. It means that the voters can determine the choices based on rational consideration. The rational choice theory, according to Antunes (2010, p. 158) must be applied on three fundamental premises, that follow: (1) all decisions those that are made by voters and political parties - are rational, (2) the democratic political system implies a level of consistency that supports predictions about the consequences of decisions made by voters and political parties, dan (3) the democratic system assumes despite the consistency stated in the previous point.

The study of rational choice has two main priciples, those are both the dominance and invariance. It had be explained by Kahneman \& Tversky (Hafidz, 2016, p. 7):

However, all analyses of rational choice incorporate two principles: dominance and invariance. Dominance demands that if prospect $\mathrm{A}$ is at least as good as prospect $\mathrm{B}$ in every respect and better than $\mathrm{B}$ in at least one respect, then A should be preferred to B. 
Invariance requires that the preference order between prospects should not depend on the manner in which they are described.

The concept of dominance show that some thing be choosen because it more excellence from another, but the excellencess must not be in a whole things, at least the thing tha be chosen has one of the aspects that superior to the other. While the concept of invariance shows that preference/the lack of interest of eligible voters to the choices that are available were not dependent on how the choice was described as.

\section{E. RESULTS AND DISCUSSION}

Election behaviour is the main characteristics of individual to do something that is known as the mixed from a variety of psychological factors, physical factors, biological factors and of the social condition which is influencing men life. In the meantime, Edwards, Secord and Becman (Azwar, 2003, p. 5) have suggested that behavior or attitude is degrees of positiveness or negative psychological toward an object as a descendant of feeling (afection), thought (cognition) and predisposing of action (conation) of someone to an aspect around the neighborhood.

Associated with the decision to determine voting patterns as the voting behavior, the students of UPI as educated young generation voters looked reveals a tendency to choose the leader by taking consideration of anything more rational and objective of the leader who they choose. This tendency reveals from their dicision to choose the leader who has both performance and leadership experience.

The main aspect that be considered by the majority of respondents is candidate/political party's vision-mission $(89.6 \%)$. And so does the consideration to candidate's performance, majority of respondents $(98.7 \%)$ considering it to make decission.

Table 1. Rational Consideration of Election Behaviour of Respondents to Decide Their Choice

\begin{tabular}{|l|l|l|}
\hline No. & Consideration & Percentage \\
\hline 1 & $\begin{array}{l}\text { Candidate's vision- } \\
\text { mission }\end{array}$ & $89.6 \%$ \\
\hline 2 & $\begin{array}{l}\text { Performance } \\
\text { experience }\end{array}$ & $96.7 \%$ \\
\hline 3 & $\begin{array}{l}\text { Education } \\
\text { background }\end{array}$ & $78.4 \%$ \\
\hline 4 & $\begin{array}{l}\text { Leadership } \\
\text { experience }\end{array}$ & $96.3 \%$ \\
\hline 5 & $\begin{array}{l}\text { Ability to build } \\
\text { region }\end{array}$ & $92.9 \%$ \\
\hline
\end{tabular}

In addition, educational background, leadership experience, and being able to build region of respondents becomes a consideration of the majority of respondents in determining the choice.

Thus, in considering the choice, respondents always trying to know and understand the condition and ability of politician/ political party that will chosen. Majority of them (77.6 \%) Ever find out about leader who will lead district. According to them, it's not a waste of time, it was proven by only $10.4 \%$ respectively of those who look at those as spending time.

Meanwhile, an assessment of a political party will be used in the basic consideration in determining the choice. Relating to respondents evaluation of this political party, it seems that trust respondents is still low. As illustrated in with a small number $(30.3 \%)$ consider that the political parties can pass their aspirations. The same thing happens in its function, a few of respondents $(39.4 \%)$ felt that political parties have fulfill their function. This means that the assessing political party credibility becomes a consideration in determining the choice. 
This fact shows that the political awarness of people show the critical thinking of political attitude in reviewing political vision-mission which is supported by politicians. The people had participated in politic actively by reviewing political values in political promises of politicians.

The people have come to realize that critical attitude are great importance to realize the better region development. By this attitude, the people can choose the leader who has vision-mission that could be accounted for significantly, and the last, they can enjoy and felt the benefits of leadership of the leader who they choose.

When faced on issues of how to explain the phenomena of changing attitude or behavior of the same voters with the same social status in make the choice from one election to the next, the thought of another variables which is influencing voting behavior appear as the thought that view the voting behaviour more rational.

The impact of religion environment, social environment, or the internal of individual aspects might give considerable influence. But, when the voter is advancing their both thinking and ability to consider everything, every political issues will always be considered to decide their choice. This sort of thing prevalent among the young generation voters, especially the collegians who had been taken some process to consider the benefit of their decision.

Related to the decision to make the choice as election behaviour, the students of UPI as educated young voters show the tendencious in choosing the leader by considering everything both rationally and objectively. This trend is apparent from its consideration to choose a leader who has both performance and adequate leadership experience. In addition, each candidate's vision-mission and background of education becomes a consideration of students of UPI to determine who they will choose.

This behaviour prove that as the educated young voters, the students of UPI prefer thought rational in choosing leader, where more or less, they could predict the consequencies of different decisions, and made it enables for other options in setting their own choice. This is in line with the opinions of Antunes $(2010$, p. 158) that there're three fundamental premises in rational choice theory, which are: (1) all decisions - those that are made by voters and political parties - are rational; (2) the democratic political system implies a level of consistency that supports predictions about the consequences of decisions made by voters and political parties. In this case, the agents (voters, parties and gouvernment) have responsibility and could be trusted, where they can predict the consequencies of different choice; (3) the democratic system assumes - despite the consistency stated in the previous point, that is a degree of uncertainty or certainty allow the different option.

Election behaviour which is based on rational consideration to the political issues rarely based by their knowledge and political insight of students of UPI which they seek and explore by themself. Meanwhile, the lack of socialization in their family and public causing their insight tend to high idealism, they gain the political issues more theoretically and practically.

Based on the review of tendency of yaoung voter electien behavior, esspecially the students of UPI as the respondents in this study, it can be concluded that the rational-objective thinking about the candidates who will be chosen became the main consideration to decide the choice. It prove that the young voters have more rational thinking to decide their choice. 


\section{F. CONCLUSION}

Based on the analysis, it could be concluded that, basically, the election behaviour of students of UPI is i nfluenced by their view on the the criteria of a good leader. Politicians/political parties vision-mission should also influence in form and a growing the worldview of each students of UPI which prove the existence of significant impact. It show the rationality of election behaviour to decide the choice in election.

The same is true for the critical thinking attitude to political parties, which the students of UPI as the novice voter, in majority, able to assess political parties performance. And it could be a basic of their consideration to decide their choice.

\section{G. ACKNOWLEDGEMENT}

Thank you to published this article in International Journal Pedagogy of Social Studies.

\section{REFERENCES}

Antunes, R.J.S. (2010) Theoretical Models of Voting. Exedra. No. 4. pp. 145-170.

Azmi, K. (2015) Perilaku Memilih Pemilih Pemula Masyarakat Kendal pada Pemilihan Umum Presiden dan Wakil Presiden Tahun 2014. Gouvernment Science Departement FISIP Undip Semarang. Accessed (online) at March $14^{\text {th }} \quad 2018$ from https://media.neliti.com/media/pub lications/111809-ID-perilakumemilih-pemilih-pemulamasyarak.pdf.

Azwar, S. (2003) Sikap Manusia, Teori dan Pengukurannya. Yogyakarta: Pustaka Pelajar Offset.

Dixon, C. and Leach, B. (1977) Sampling Methods for Geographical Research. London: Catmog 17Institute of British Geographers.
Hafidz, E.S. (2016) Teori Pilihan Rasional. Researchgate. Accessed (online) at October $29^{\text {th }} 2018$ from: https://www.researchgate.net/ publication/318774284.

Hasriani, Madani, M., and Handam (2015) Perilaku Pemilih Pemula dalam Pemilihan Presiden dan Wakil Presiden Tahun 2014 di Kelurahan Sapaya Kecamatan Bungaya Kabupaten Gowa. Otoritas. Vol. V (1). pp. 52-65.

Higashikata, T. and Kawamura, $\mathrm{K}$. (2015) Voting Behaviour in Indonesia from 1999 to 2014: Religious Cleavage or Economic Performance? IDE Discussion Paper. Vol. 512. IDE-JETRO Japan.

Salahudin (2016) Rasionalitas Janji Politik dalam Pilkada. Researchgate. Artikel September 2016. Accessed (online) at October $29^{\text {th }} \quad 2018$ from: https://www.researchgate.net/publi cation/307901148.

Steiner, J. (1990) Rational Choice Theory and Politics: A Research Agenda and a Moral Question. The Cambridge Core. University of Basel Library. pp. 46-50. Accessed (online) at October $29^{\text {th }} 2018$ from: https:/www.

cambridge.org/core/terms. https://doi.org/10.2307/419777.

Sugiyono (2012) Metode Penelitian Kuantitatif, Kualitatif, dan $R \& D$. Bandung: Alfabeta.

Indonesia Republic Constitution No. 1/2015 about Establishment of Gouvernment Law for Substitute Constitution No. 1/2014 about Governor, Regent, and became Constitution.

Indonesia Republic Constitution No. 7/2017 about Election.

Indonesia Republic Constitution No. $8 / 2015$ about yhe Changes of 
Indonesia Republic Constitution No. 1/2015 about Establishment of Gouvernment Law for Substitute Constitution No. 1/2014 about Governor, Regent, and became Constitution.

Zidni, M.F. (2014) Perilaku Memilih (Dinamika Pilihan Rasional dalam
Kemenangan Jokowi-Basuki pada Pemilihan Umum Gubernur DKI Jakarta 2012). Thesis of Political Science Program FISIP UIN Syarif Hidayatullah Jakarta. 